\title{
High-rate Fertilization of Native Rangeland in Oregon
}

\author{
DONALD M. BALDWIN, NEWTON W. HAWKINSON, AND E. WILLIAM ANDERSON
}

Highlight: $A$ single application of 27-12-0 fertilizer on native rangeland in northwestern Oregon produced a 4-year total herbage production of 15,789 lb/acre, air dry with $1,100 \mathrm{lb}$ of fertilizer; $18,383 \mathrm{lb} /$ acre with $2,200 \mathrm{lb}$ of fertilizer; and 16,477 $\mathrm{lb} / \mathrm{acre}$ with 4,400 $\mathrm{lb} / \mathrm{acre}$ of fertilizer. Unfertilized plots produced 5,932 lb/acre. Increasing the rate of fertilization improved the vigor of perennial grasses, increased utilization of herbage by cattle, extended the green-forage season, and temporarily increased nitrate nitrogen in the forage. High-rate fertilization markedly increased Kentucky bluegrass in the composition.

One of the last unfertilized areas in United States agriculture is the upland range. Prior to and including the early 1960's, fertilizer trials on native upland ranges had produced erratic responses (Hull, 1963). More recently, studies using very high rates of nitrogen $(\mathrm{N})$ and other nutrients stimulated new interest in range fertilization. Montana range was successfully fertilized with $600 \mathrm{lb}$ of $\mathrm{N} /$ acre (Choriki et al., 1969). An extreme rate of 900 pounds of nitrogen per acre was used in Texas (Drawe and Box, 1969). Fertilization rates of up to $240 \mathrm{lb}$ of N/acre have been used in British Columbia, Canada (Mason and Miltmore, 1970).

This study consists of a 10-year demonstration trial started in 1969 to further test the concept of high-rate fertilization on rangeland. Such iertilization, if proven practical, could offer the opportunity to increase herbage production and quality and to improve utilization.

The fertilizer applied in this trial was 27-12-0, which was selected for several reasons. First, its nitrogen, phosphate and sulfur nutrient ratio closely approximates the balance of nutrients contained in the forage of many grasses (Woodhouse, 1962). Second, phosphate was intentionally included in the fertilizer used to

Authors are district conservationist, U.S. Department of Agriculture, Soil Conservation Service, Enterprise, Oregon; field agronomist, Chevron Chemical Company, Portland, Ore.; and state range specialist, U.S. Dep. Agr., SCS, Portland, Ore.

The authors wish to thank Dr. M. H. McVickar for his help and encouragement in the project. Also thanks to Mr. Charles Gavin and cooperating ranchers and local businessmen who gave support to the project.

Manuscript received February 10, 1973. increase herbage utilization (Drawe and Box, 1969) and to improve frost tolerance (McVickar, 1970). Third, the sulfur in the mixture reduces chances of sulfur deficiency occurring at the high nitrogen fertilizer demonstrations previously conducted on both dryland and irrigated pastures in Wallowa County, Oregon, have shown that 27-12-0 fertilizer is superior to others tested under local conditions.

This paper is a progress report of the first 4 years of the study. A final report and an economic evaluation will be prepared when the study is completed.

\section{Procedure}

The site for the trial is in the Zumwalt area of Wallowa County in northeastern Oregon. It is located at $4,800 \mathrm{ft}$ elevation and receives 16 to 18 inches of annual precipitation, about $45 \%$ of which falls during the growing season of April through July. The soil is Zumwalt silt loam, which consists of about 36 inches of loess over basalt bedrock. The plant association in this Palouse Prairie grassland is dominated by Idaho fescue (Festuca idahoensis Elmer) and Sandberg bluegrass (Poa sandbergii Vasey). Mixed forbs are prominent in the stand.

A single application of 27-12-0 fertilizer containing $4 \%$ sulfur was applied at rates of $0 ; 1,100 ; 2,200$; and 4,400 $\mathrm{lb} /$ acre. Fertilizer was applied on April 13, 1969, using a small garden-type spinning fertilizer spreader. Plots were 10 by $40 \mathrm{ft}$ in size, and four replications were included in the randomized block design. Plots were fenced to control grazing. rate (Steward, 1969). Finally, unreported
Herbage was harvested by hand from plots $3.3 \mathrm{ft}$ square in June 26,1969 , July 8, 1970, July 8, 1971, and July 25, 1972. Herbage was clipped to a height of 1.5 inches which, in that locality, simulates safe degree of utilization on Idaho fescue when the range is deferred during the full growing season and grazed only after seed is formed. The herbage was air dried for yield determinations.

\section{Results}

\section{Production}

Herbage production has shown response to a single application of fertilizer in each of the first 4 years of this trial (Table 1). In 1969, the year fertilizer was applied, herbage production was significantly less for the $4,400 \mathrm{lb} /$ acre rate than for other rates of fertilization. This might have been due to adverse first-year effects of the high rate of nitrogen applied. In subsequent years, however, a significant depression of yields did not occur with high-rate nitrogen application. Herbage production obviously has been increased by fertilization in each of the 4 years of the trial.

In spite of depressed yields at the highest fertilizer rate in 1969 , all plots showed vigorous growth at harvest time. Idaho fescue and Sandberg bluegrass made up the majority of the herbage in the samples. Dandelion (Taraxacum officinale Weber) was abundant in plots fertilized at the higher rates. A variety of forbs occurred in all plots but did not respond noticeably to fertilizer rates.

Herbage production in 1970 showed continued response to fertilizer applied in 1969. As explained later, the overgrazing in 1969 on highest-rate plots may have had a depressing effect on yields in 1970. However, this may also be partially attributable to high-rate nitrogen application. Severe overgrazing of highestrate plots in 1969 resulted in some barren ground in 1970 and a strong encroachment of annuals including mustards 
Table 1. Response of herbage yield (lb/acre) ${ }^{1}$ on native rangeland to a single application of 27-12-0 fertilizer (lb/acre) containing $4 \%$ sulfur.

\begin{tabular}{|c|c|c|c|c|c|c|c|c|}
\hline \multicolumn{4}{|c|}{ Treatment } & \multicolumn{5}{|c|}{ Year of measurement } \\
\hline $\begin{array}{c}\text { Fertil- } \\
\text { izer }\end{array}$ & $\mathrm{N}$ & $\mathrm{P}_{2} \mathrm{O}_{5}$ & $\mathrm{~S}$ & 1969 & 1970 & 1971 & 1972 & Total \\
\hline 0 & - & - & - & $1,042 \mathrm{c}$ & $1,615 \mathrm{c}$ & $1,662 \mathrm{~b}$ & $1,613 b$ & $5,932 \mathrm{~b}$ \\
\hline 1,100 & 297 & 132 & 44 & $4,667 \mathrm{a}$ & 3,591 bc & $4,339 \mathrm{a}$ & 3,192 a & $15,789 a$ \\
\hline 2,200 & 594 & 264 & 88 & $4,875 \mathrm{a}$ & $6,590 \mathrm{a}$ & 4,282 a & $2,636 \mathrm{ab}$ & $18,383 \mathrm{a}$ \\
\hline 4,400 & 1,184 & 528 & 176 & $2,979 \mathrm{~b}$ & $5,301 \mathrm{ab}$ & $5,350 \mathrm{a}$ & $2,847 \mathrm{ab}$ & $16,477 \mathrm{a}$ \\
\hline
\end{tabular}

${ }^{1}$ Means within a column followed by the same letter are not significantly different at the $5 \%$ level.

(Brassica spp.), cheatgrass (Bromus tectorum L.) and fanweed (Thlaspi arvense L.). Kentucky bluegrass (Poa pratensis L.) increased markedly in the composition. There were fewer plants of Idaho fescue in 1970 than in 1969 , but they were more vigorous.

In 1971 , the effect of fertilizer was still evident on all plots. Perennial grasses and forbs were dominant on plots fertilized at the rates of 1,100 and 2,200 $\mathrm{lb} / \mathrm{acre}$. Annuals such as mustard and cheatgrass were still prominent on plots fertilized at the $4,400 \mathrm{lb} /$ acre rate, but they were being crowded by Idaho fescue and Kentucky bluegrass. The perennial grasses were vigorously revegetating barren areas.

\section{Grazing}

The plots were grazed by cattle in August, 1969, after production was measured, to test the effects of fertilization rates on palatability of mature forage. Inadvertently, the cattle were allowed access to the plots for too long a time. The degree of utilization by cattle was related to the rate of fertilization. Check plots were virtually untouched. Plots fertilized with $1,100 \mathrm{lb} /$ acre were grazed to an average stubble height of about 2 inches. Plots fertilized with $2,200 \mathrm{lb} /$ acre were moderately overgrazed to a stubble height of about one inch. Plots fertilized with $4,400 \mathrm{lb} /$ acre were severely overgrazed-grubbed to the ground line-and this could account for the depressed herbage yield on these plots in 1970. This pattern of utilization was consistent on all four replications.

The plots were not grazed in 1970, but they were mowed in the fall to simulate grazing and the herbage was removed.

Table 2. Nitrate nitrogen levels (\%) in native range forage after a single high-rate application of 27-12-0 fertilizer.

\begin{tabular}{lllll}
\hline & \multicolumn{4}{c}{ Fertilizer rates (lb/acre) } \\
\cline { 2 - 5 } Year & 0 & 1,100 & 2,200 & 4,400 \\
\hline 1969 & 0.028 & 0.072 & 0.24 & 0.22 \\
1970 & 0.09 & 0.09 & 0.10 & 0.20 \\
\hline
\end{tabular}

Cattle were allowed to graze the plot area for 4 days after clippings were made in 1971. In that short length of time, the cattle completely harvested plots fertilized with 4,400 lb/acre and had started to graze plots fertilized with $2,200 \mathrm{lb} /$ acre. Plots fertilized with $1,100 \mathrm{lb} / \mathrm{acre}$ and control plots were virtually ungrazed. In both 1969 and 1971 cattle completely utilized all herbage on highest-rate plots including mustards, cheatgrass, and fanweed.

In 1972 , cattle were allowed to graze the plots for about 1 week in the autumn following herbage measurements. Essentially the same pattern of utilization was obtained as in 1971 .

\section{Nitrate Nitrogen}

Herbage samples from each plot were analyzed in 1969 for nitrate nitrogen. In 1970 , a composite sample of herbage from the four replications was made for each rate of fertilizer and analyzed for nitrate nitrogen (Table 2). Nitrate nitrogen levels above $0.21 \%$ are considered toxic (Fanning, 1969). One plot sample analyzed $0.35 \%$ and another $0.4 \%$ nitrate nitrogen, well above toxic levels. There was an abundance of forbs on fertilized plots which may have been related to these high levels, since other workers have found that forb species are commonly associated with high nitrate nitrogen levels (Dodge, 1970). Plots were not analyzed for nitrate nitrogen in 1971 and 1972 because the amount had dropped below toxic levels in 1970 .

\section{Green Forage Season}

Length of green forage season was noticeably affected by fertilization. At all rates of fertilization, fertilized plots stayed green at least 6 weeks longer into the summer than did unfertilized plots. Each year, unfertilized plots dried up in early July, whereas fertilized plots were still green in late August.

Five days after harvest in 1969, six inches of regrowth was measured on the Idaho fescue plants in plots fertilized with 2,200 and 4,400 lb/acre. Regrowth on plots fertilized at the $1,100-\mathrm{lb} /$ acre rate was about 2 to 3 inches. Practically no regrowth occurred on the unfertilized plots. This pattern of regrowth has been observed each year since.

Fertilized plots started growth earlier in the spring than did unfertilized plots. In early April, 1970, Idaho fescue had four inches of growth and a deep green color on all the fertilized plots. No new growth was apparent on the unfertlized plots.

\section{Summary and Conclusions}

High-rate application of $27-12-0$ fertilizer increased herbage production and plant vigor on native rangeland in each of the first 4 years of the trial. Perennial grasses such as Idaho fescue and Sandberg bluegrass gave good response to high-rate fertilizer application. Fertilization extended the green-forage season by 6 weeks or more each summer and increased the utilization of mature herbage by livestock. There is a carryover effect of fertilizer that is continuing after several years.

On the other hand, the two highest rates of fertilization increased the concentration of nitrate nitrogen in herbage to toxic levels in 1969, the year fertilizer was applied. High-rate fertilization increased the degree of utilization by cattle so much that careful grazing management would have to be practiced or the range resource could be damaged seriously.

Based on preliminary results, it appears that the concept of high-rate fertilization of certain kinds of rangeland does have promise as a tool for range managers in the future. Used wisely as a part of a good grazing management program, it could produce many benefits. It could cconomically increase the total forage produced in a pasture. It could improve the grazing distribution and pattern of use within a pasture. It could extend the green-forage season and provide higher quality feed later into the summer. It could improve the vigor of native perennial grasses faster than grazing management alone can do. It will provide benefits over a period of years from a single application.

High-rate fertilization also might be used effectively in managing rangelands for big game and other wildlife. It might have a significant place in watershed improvement and management. It might well be an answer to maintaining recreational areas that receive concentrated use.

Additional research is needed to further study high-rate fertilization of vari- 
ous kinds of rangelands. Special attention should be given to undesirable changes in the composition that might occur.

\section{Literature Cited}

Choriki, Raymond T., D. E. Ryerson, and A. L. Dubbs. 1969. Evaluation of nitrogen use and methods of application on mixed prairie vegetation in Montana in relation to forage yield, change in composition of vegetation, residual nitrogen, nitratc poisoning, and beef gain per acre. 182-186 In Proc. 20th Annu. Fertility Conf. of the Pacific Northwest, Spokane, Washington, July 8-10, 1969.
Dodge, Marvin. 1970. Nitrate poisoning, fire retardants, and fertilizers-any connection? J. Range Manage. 23:244-247.

Drawe, L.D., and T. W. Box. 1969. High rate of nitrogen fertilization influence coastal prairie range. J. Range Manage. 22:32-36.

Fanning, C. D. 1969. Nitrate levels in heavily fertilized forages in eastern Washington. Washington State Univ. Pamphlet EM3287.

Hull, A. C. 1963. Fertilization of seeded grasses on mountainous range lands in northeastern Utah and southeastern Idaho. J. Range Manage. 16:306-310.

Martin, W. E., Cecil Pierce, and V. P. Osterli. 1964. Differential nitrogen response of annual and perennial grasses. J. Range Manage.
17:67-68.

Mason, J. L., and J. E. Miltmore. 1970. Yield increases from nitrogen on native range in southern British Columbia. J. Range Manage. 23:128-131.

McVickar, Malcolm H. 1970. Using commercial fertilizers. Interstate Printers and Publishers, Danville, Illinois.

Steward, B. A. 1969. Nitrogen-sulfur relationships as a guideline for assessing sulfur needs. p. 142-149 In Proc. 20th Annu. Fertility Conf. of the Pacific Northwest, Spokane, Wash. July 8-10, 1969.

Woodhouse, W. W., Jr. 1962. Forages. 2nd Ed. Iowa State University Press. 